BIOC (Biodiversity and Conservation) 2013 22(10):2353-2374

Camilla Wellstein, Stefano Chelli, Giandiego Campetella, Sandor Bartha, Marco Galiè, Francesco Spada, Roberto Canullo

\title{
Intraspecific phenotypic variability of plant functional traits in contrasting mountain grasslands habitats
}

C. Wellstein* - Department of Biogeography, University of Bayreuth, Universitat sstr. 30, 95440 Bayreuth, Germany, * e-mail: camilla.wellstein@ uni-bayreuth.de

Bayreuth Centre for Ecology and Environmental Research BayCEER, Dr.-Hans-Frisch-Straße 1-3, 95448 Bayreuth, Germany

S. Chelli, G. Campetella, R. Canullo - Lab. of Plant Population Ecology, School of Environmental Sciences, University of Camerino, Via Pontoni, 5, Camerino, 62032 Macerata, Italy

S. Bartha - Centre for Ecological Research, Institute of Ecology and Botany, Hungarian Academy of Sciences, Alkotmány út 2-4, 2163 Vácrátót, Hungary

M. Galiè - Interdipartimentale Centre of Botanical Garden, Marche Polytechnic University, Via Brecce Bianche, Monte Dago, 60131 Ancona, Italy

F. Spada - Department of Environmental Biology, University of Rome "La Sapienza", Botanical Garden of Rome, Largo Cristina di Svezia 24, 00165 Rome, Italy

\begin{abstract}
Empirical studies that link plants intraspecific variation to environmental conditions are almost lacking, despite their relevance in understanding mechanisms of plant adaptation, in predicting the outcome of environmental change and in conservation. Here, we investigate intraspecific trait variation of four grassland species along with abiotic environmental variation at high spatial resolution $(n=30$ samples per species trait and environmental factor per site) in two contrasting grassland habitats in Central Apennines (Italy). We test for phenotypic adaptation between habitats, intraspecific trait-environment relationships within habitats, and the extent of trait and environmental variation. We considered whole plant, clonal, leaf, and seed traits. Differences between habitats were tested using ANOVA and ANCOVA. Trait-environment relationships were assessed using multiple regression models and hierarchical variance partitioning. The extent of variation was calculated using the coefficient of variation. Significant intraspecific differences in trait attributes between the contrasting habitats indicate phenotypic adaptation to in situ environmental conditions. Within habitats, light, soil temperature, and the availability of nitrate, ammonium, magnesium and potassium were the most important factors driving intraspecific trait-environment relationships. Leaf traits and height growth show lower variability than environment being probably more regulated by plants than clonal traits which show much higher variability. We show the adaptive significance of key plant traits leading to intraspecific adaptation of strategies providing insights for conservation of extant grassland communities. We argue that protecting habitats with considerable medium- and small-scale environmental heterogeneity is
\end{abstract}


important to maintain large intra-specific variability within local populations that finally can buffer against uncertainty of future climate and land use scenarios.

Keywords

Clonal growth, Intraspecific trait variation, Leaf traits, Phenotypic adaptation, Phenotypic plasticity, Seed mass

Abbreviations

SLA Specific leaf area

LDMC Leaf dry matter content

Nomenclature

Pignatti (1982) for taxa; Venanzoni \& Kwiatkowski (1995) for the syntaxa mentioned in Table 1.

Electronic supplementary material

The online version of this article (doi:10.1007/s10531-013-0484-6) contains supplementary material, which is available to authorized users.

Introduction

Trait-based approaches increasingly contribute to link environmental changes with plant community variation (e.g. Webb et al. 2010; Wellstein et al. 2011). Studies on interspecific trait-environment relationships make it clear that plant species are related to environmental conditions via their functional traits (e.g. Poorter et al. 2009). However, trait variation extends beyond interspecific differences being affected by intraspecific phenotypic and genetic variation (Albert et al. 2010; Nicotra et al. 2010). Intraspecific (i.e. within-species) variation is partly due to phenotypic plasticity, i.e. the production of multiple phenotypes from a single genotype (e.g. Miner et al. 2005). Phenotypic plasticity gives a plant the ability to adjust its performance by altering morphology and/or physiology in response to varying environmental conditions throughout its lifespan. This phenotypic adaptation is also named phenotypic accommodation (see West-Eberhard 2005; Badyaev 2009) and is considered to confer a benefit on the organism with regard to its present relationship with its environment (Sultan 1987). Moreover, intraspecific variation can be caused by inheritable differences in gene expression and function (i.e. epigenetic changes, addressed as microevolution, Bossdorf et al. 2008) and by differences in the genotype which can be induced by local long-term adaptation to the environment (i.e. evolution).

Since plants as sessile organisms are known for their functional variation within both species and individuals (Miner et al. 2005; Hulshof and Swenson 2010), it is likely that finerscale trait variation plays an important role in controlling species establishment and persistence (e.g. Violle et al. 2012). Actually, it has been proved that many plant populations exhibit significant phenotypic variation for a range of traits within very small areas (Linhart and Grant 1996), including life-history characters (Linhart 1988), pathogen and herbivore resistance (Burdon 1987; Simms 1990), and nutrient allocation related to resource capture and competitive ability (Turkington and Aarssen 1984; Turkington 1989). Intraspecific trait variation may lead to phenotypic differentiation resulting in different abilities of plants to cope with environmental change, i.e. phenotypic specialization (e.g. Bolnick et al. 2003). In this context, the adaptive capacity of traits related to specific ecological processes such as dispersal, establishment, competition, regeneration and flowering, might be of particular 
importance. While these traits have been tested for variation across communities taking into account relative species cover (community-weighted means (CWM), e.g. Garnier et al. 2004; Wellstein and Kuss 2011), their intra-specific variation in response to changing environmental conditions has rarely been tested so far. The knowledge on the mechanisms and of the extent of plant adaptation is a prerequisite when predicting the outcome of climate and land use changes. At the same time, there is an increasing demand to incorporate climate change issues into conservation planning (e.g. Groves et al.2012; Mawdsley et al. 2009).

Since the analysis of trait variation along gradients and under contrasting environmental conditions provides an approach to quantify intraspecific variation and niche breadth of individual species (Ackerly and Cornwell 2007), it is of high interest to test for phenotypic adaptation in this context. We selected key plant traits and environmental conditions, which are likely candidates to stay in trait-environment relationships according to evidence in current literature (Table 2). Those traits were sampled by a large amount of individuals, in order to cover the phenotypic variability of leaf, seed, clonal and whole plant traits in four representative species of montane nutrient poor dry grassland ecosystems (Sesleria nitida, Lotus corniculatus, Astragalus sempervirens, Thymus longicaulis) in two habitats with contrasting environmental conditions in terms of soil chemical, physical parameters and light availability.

We hypothesize that phenotypic variation of leaf, seed, clonal and whole plant traits is adaptive at small geographical scales (i.e. few $100 \mathrm{~m}$ to few centimetres). In detail, we hypothesize that trait attributes of species significantly differ between habitats with contrasting environmental characteristics (H1), and that trait attributes are linked to environmental gradients within a habitat $(\mathrm{H} 2)$. Furthermore, we explore the relationship between trait and environmental variation, searching for conservative, regulated versus highly plastic traits. Finally, we discuss the implications of our findings for nature conservation and climate change adaptation.

\section{Materials and methods}

\section{Study area and site selection}

The Nature Reserve 'Montagna di Torricchio' (Central Apennines, Italy, online resource ESM 1a) provides areas of montane grasslands under different environmental conditions. The ones considered in this study are located in contrasting habitats, on north and on south-facing slopes along the SW-NE orientated valley (Val di Tazza), between 1,100 and 1,200 $\mathrm{m}$ a.s.1. Mean annual precipitation reaches $1,250 \mathrm{~mm}$ and mean annual temperature is around $11{ }^{\circ} \mathrm{C}$ (Halassy et al. 2005). Jurassic-Cretaceous limestone (scaglia rosata) prevails in the area. The Reserve is under protection regime since 1970; consequently the grazing activities are forbidden since that time. Previously, the grasslands were grazed mostly by sheeps and cows, sometimes also by small groups of horses. We selected two study sites with an area of about 1 ha each representing the contrasting environmental conditions of the north and south slope (online resource ESM 1b; Table1). The north-facing slope (habitat $\mathrm{N}$ ) is covered with a dense grassland assigned to the association $S$. nitidae-Brometum erecti, here a semi-mesic secondary community originated by the destruction of a former beech forest. The south-facing slope (habitat $\mathrm{S}$ ) hosts open grassland with a more scanty cover, assigned to Asperulo purpureae-Brometum erecti, a more xerophilic, mostly secondary community replacing both a beech forest as well as the local uppermost fringe of a mixed sub-Mediterranean open forest dominated by Ostrya carpinifolia and Quercus spp. Paleobotanical and archaeological evidence (see Branch 2012; Barker et al. 1991, for reviews) suggest the onset of the 
deforestation of the beech forest at higher elevations close to the summits in most of the northern and central Apennines, to date back to the time of the spread of pastoralism and the establishment of the altitudinal transhumance in the area, at 4,700 cal. years BP, a period with warmer and drier conditions than at Middle Holocene.

Nevertheless, rocky outcrops, poorly developed, shallow, skeletal soils or solifluction on steeper slopes occur all over the study area, due to its geological assessment (Kwiatkowski and Venanzoni1994). These sites, located far below the climatic treeline at this latitude (1,900-2,000 m a.s.l.) could hardly carry a close canopy, if any, of forest trees, even in absence of human disturbance. They can therefore be suggested as primary stands of "permanent" communities of more or less xerophilic grasslands, already growing "in situ" before the Copper- and Bronze Age deforestation, from which the present day, widespread, secondary grasslands developed. This grassland/forest mosaic close to summits and its changes induced by a long history of grazing can be considered as a general pattern all over the study area.

\section{Study species}

From a list of species occurring in both habitats we selected four perennial representatives of montane grasslands: S. nitida ssp. nitida (Poaceae), T. longicaulis (Lamiaceae), $L$. corniculatus L. (Fabaceae), A. sempervirens (Fabaceae). Due to their more or less accentuated degree of orophytism, they can be assumed as persistent component of these grasslands during the late-glacial/holocene. The frequency of each species in each habitat is given in the online resource ESM 1c. These species represent different life forms in the community, i.e. grass, woody forb, legume, and dwarf shrub. The grass $S$. nitida is an efficient colonizer on scree and rocky outcrops; it has a secondary root system which is restricted to the upper soil layer. The species exhibits a high capacity of clonal growth by epigeogenous rhizomes. $S$. nitida is very abundant and dominant in the habitat $\mathrm{N}$ and is abundant but scattered as thick tussocks in the habitat S. The woody forb T. longicaulis develops a tap root and forms a dense mat with thin stems, often prostrate and creeping (Pignatti 1982). It has a high capacity of vegetative spread by horizontal above ground stems. T. longicaulis is very abundant in habitat $\mathrm{S}$ but is also widespread in habitat $\mathrm{N}$ where it is scattered in small patches on rocky outcrops and on shallow soil. L. corniculatus, one of the most important legume species in dry and nutrient poor grasslands, is less abundant on both slopes but shows a similar distribution pattern. The species can grow clonally by hypogeogenous rhizomes (own observations from the present study), it develops tap roots and has a high capacity to withstand soil erosion and is a highly efficient accumulator of nitrogen, for which it is used also in agricultural management (Carter et al.1997). The dwarf shrub A. sempervirens is a spiny, long-living species (over many decades) growing in summit grasslands on limestone (Pignatti 1982). It is not capable of clonal growth; it produces deep-reaching tap roots which enable the species to withstand erosion and to reach deeper water reserves in the soil. A. sempervirens is quite rare and has the same density on both slopes; it grows on patches with deeper soil or alternatively uses cracks in the rocks for the development of its tap root.

\section{Sampling of plant traits and environmental parameters}

For each species in each habitat we randomly selected thirty robust, well grown and adult individuals without symptoms of pathogen or herbivore attack. All field sampling of plant and environmental parameters was done from June 26th to 30th in 2010. In each selected individual we measured the following traits that are associated with different life-history processes (see Table 2): (i) leaf traits (specific leaf area [SLA]; leaf dry matter content 
[LDMC]), (ii) whole plant traits (height; horizontal stem length), (iii) clonal traits (no. of bifurcations/nodes per $\mathrm{cm}$; distance between bifurcations/nodes) (see Table 2). As an exception, seed traits (iiii) (i.e. seed mass and seed germination), were measured from a random rate of seeds collected from all individuals in each habitat. The trait sampling followed standard procedures (Cornelissen et al. 2003; Kleyer et al. 2008). In particular, leaf traits were measured on three leaves per individual; after the measurement of the fresh weight and area, the leaves were oven-dried $\left(80{ }^{\circ} \mathrm{C}\right.$ for $48 \mathrm{~h}$ ) to measure their dry weight. The plant height and horizontal stem length were measured in the field, while the clonal traits were determined in the laboratory on the harvested individuals. Seeds were air-dried and manually cleaned; seed mass was calculated using a balance with accuracy $0.0001 \mathrm{~g}$. Germination tests were carried out at Germoplasm Bank for ex situ conservation of anfiadriatic plant species (ASSB), according to the international seeds germination protocols (ISTA 1999). Seeds were sown in Petri dishes with $1 \%$ of bacteriological agar and germination was tested at $20{ }^{\circ} \mathrm{C}$ constant temperature and 12/12 h photoperiod. We tested four replicates of 25 seeds for each species per habitat; this represents a commonly used amount of seeds in ecological studies. The germination tests were completed after 30 days.

For the functional traits, only $9 \%$ of the values are lacking. This originated from the absence of seeds in L. corniculatus in the habitat $\mathrm{N}$ during the sampling season. In habitat $\mathrm{S}$ seeds were usually present.

Additionally, in order to adjust analyzes for plant size, we sampled the biomass of all individuals of $L$. corniculatus and $T$. longicaulis. We collected the entire individual, i.e. above and belowground biomass; samples were oven-dried at $80{ }^{\circ} \mathrm{C}$ for $48 \mathrm{~h}$ and weighted (accuracy: $0.001 \mathrm{~g}$ ). In case of $S$. nitida, it was not reasonable to adjust for plant size, since the species does not develop huge individuals because clonal offspring disintegrates after some years resulting in no differences appearing with age. In case of A. sempervirens we were not allowed to collect the plant specimen for biomass measurements in the nature reserve.

We used a sample size (30 individuals per species per habitat) 3 times larger than the one required by standard protocols (e.g. Cornelissen et al. 2003) for measuring plant traits in order to take into account the effects of environmental heterogeneity of the habitats. Soil physical and chemical parameters and light availability were measured at the exact position of each sampled plant individual. Soil samples were taken only after the measurements of traits in the field.

The sunlight reaching the canopy [Photosynthetic Active Radiation (PAR)] was measured using a PAR/LAI Ceptometer (LP80 AccuPAR—Decagon Devices, inc.). The percentage of soil moisture and the soil temperature $\left({ }^{\circ} \mathrm{C}\right)$ were measured using a humidity and temperature probe meter ( $\operatorname{Tr} 46908)$. For the analysis of soil chemical parameters, a soil sample ( $3 \mathrm{~cm}$ diameter, usually $10 \mathrm{~cm}$ depth; on rocky outcrops the soils were more shallow) was taken at the exact position of each plant individual. We determined the $\mathrm{pH}$ value and conductivity (in water), the total nitrogen ( $\mathrm{Nt}$ ) and total carbon $(\mathrm{Ct})$ content (CNA analyzer FlashEA 1112, Thermoquest) and the $\mathrm{CaCO}_{3}$ (Calcimeter 08.53, Eijkelkamp) according to Scheibler (Hoffmann1991). The $\mathrm{C} / \mathrm{N}$ ratio was calculated considering that total carbon minus the $\mathrm{CaCO}_{3}$-carbon gives the organic carbon in the soil.

Samples were extracted with calcium-acetate-lactate (CAL) for the determination of plant available phosphorus $\left(\mathrm{P}_{\mathrm{CAL}}\right)$ and potassium $\left(\mathrm{K}_{\mathrm{CAL}}\right)$ (Hoffmann 1991) as well as nitrate(NO3-) and ammonium $\left(\mathrm{NH}_{4}+\right.$ ) (FIA, flow injection analysis, Firma MLE). The elements K, Mg and P were determined with the ICP-OES (Vista-Pro) spectrometer (Varian).

Data analyses

248 
Significant differences in environmental variables between species and habitats (at the place of growth of individuals of each species) were evaluated by two-way ANOVA, followed by post hoc test (Tukey HSD). Main effect of habitat, species and their interactions are given in Table 3.

For S. nitida and A. sempervirens, ANOVA was used to test for the significance of differences in functional trait values between the two habitats. For $L$. corniculatus and $T$. longicaulis, ANCOVA was used to adjust for the effect of plant size (biomass) and to test for the significance of differences in functional trait values between the two habitats (e.g. McCarthy and Enquist 2007).

For seed germination, ANOVA was used since no biomass data were available for plants from which seeds were collected. Prior to statistical analysis, the traits values were log transformed when conditions of normality were not met or in order to improve homogeneity of variances. In all analyses, the level of significance was $p<0.05$.

We applied linear regression and hierarchical variance partitioning to evaluate the intraspecific trait-environment relationship for each trait per species and habitat. For each trait (response variable), we fitted the full model of all measured environmental parameters, leading to 12 distinct models per species. In case a model revealed a significant traitenvironment relationship we applied hierarchical variance partitioning and subsequent bootstrapping (package relaimpo, Grömping 2006) in order to evaluate the relative importance of explanatory environmental variables on a certain trait (Grömping 2006; Murray and Conner 2009). Prior to analyses, data were log, square root or arcsin transformed when necessary. For linear regression, ANOVA and ANCOVA we used the package nlme.

Additionally, we use the coefficient of variation (CV; SD divided by the mean) as a relative measure of phenotypic variability in order to assess and compare the degree of trait and environmental variation within habitats. The CV has frequently been used in the context of environmental and trait variation (e.g. Lemke et al. 2012). We calculated the CV for each trait of a species and for each environmental parameter (measured at the place of growth of the individuals of each species) within a habitat (Table 5) as well as throughout species and habitats (Table 6). We used quartiles based on data of all parameters for all species within and throughout habitats (data not shown) to categorize four classes of variation (CV) for environmental parameters as well as for traits, i.e. low, medium, high, and very high CV (online resource ESM 2).

Our further investigation of the relationships of trait- and environmental variation (CV-CV graphs, Fig. 1) is based on the results of linear regression and hierarchical variance partitioning as we investigated the most important, significant trait-environment relation-ships (Table 5). Each $\mathrm{CV}-\mathrm{CV}$ graph contains a reference line which allows distinguishing if a trait varies more than expected from the null model. The null model is that in evolution the trait variability follows the variability of the environment. Values of traits that lay above the reference line indicate higher trait variability, values below the line indicate lower variability than expected (Fig. 1).

All statistical analyses were performed using $\mathrm{R}$ (Version 2.13.1) (R Development Core Team 2010).

\section{Results}

Phenotypic differences between habitats

All tested environmental factors, i.e. light availability (PAR), water availability (soil moisture), nutrient availability (plant available phosphorous, plant available potassium, 
magnesium, nitrate, ammonium, $\mathrm{C} / \mathrm{N}$ ratio, soil $\mathrm{pH}$, soil conductivity), and soil temperature, were significantly different between the two habitats (Table 3). This contrast was mirrored by significant differences in mean values of leaf traits, whole plant traits, clonal traits and seed traits within species between the two habitats (Table 4). The grass $S$. nitida and the dwarf shrub $A$. sempervirens exhibited significantly different trait attributes for all tested traits. The legume $L$. corniculatus showed significant differences in $2 / 3$ of the traits, but no differentiation in the clonal traits (number of nodes and distance between nodes) was observed. The woody forb T. longicaulis differed in half of the traits but no differentiation in LDMC, in clonal traits (number of nodes and distance between nodes), and in germination rate was observed (Table 4).

Intraspecific trait-environment relationships within habitats

Based on linear regression and the results of hierarchical variance partitioning, throughout habitats and traits the most important, significant drivers of trait-environment relationships in sequence are soil temperature, $\mathrm{NO}_{3}$, light, $\mathrm{NH}_{4}$, magnesium and potassium (Table 5, online resource ESM 3).

In at least one of the study species, these parameters strongly and significantly affected at least one trait. Twice as much trait-environment relationships were seen in the north-facing slope compared to the south-facing slope. The SLA showed an increase with increasing nitrate availability In A. sempervirens on the south-facing slope; the LDMC showed an increase with increasing magnesium availability but a decrease with increasing potassium availability in $T$. longicaulis on the north-facing slope. Height growth was negatively associated with soil temperature in A. sempervirens on the south-slope, in L. corniculatus on both slopes, and positively influenced by light and the $\mathrm{C} / \mathrm{N}$ ratio in the later species on the south-slope. On the north-facing slope, the horizontal stem length of the clonal S. nitida was positively associated with the availability of magnesium, but negatively associated with the availability of potassium and phosphorus, and with conductivity; in the clonal T. longicaulis, stem length was negatively associated with the availability of ammonium. On the north-facing slope, in T. longicaulis, the number of nodes per $\mathrm{cm}$ responded positively to light and negatively to nitrate, potassium and soil moisture; the distance between the nodes was positively associated with the availability of potassium, phosphorous and magnesium. On the south-facing slope the distance of nodes in L. corniculatus exerted a positive association with soil temperature and negative one with the $\mathrm{pH}$ (Table 5 ).

Environmental and intraspecific variability within habitats

Detailed information on the plasticity of traits and environmental variables (measured as the $\mathrm{CV}$ ) is provided in the online resource (ESM 2). Generally, the plasticity of LDMC was very low, of SLA and horizontal stem length was intermediate, and of number of bifurcations/nodes and distance between bifurcations/nodes was very high (Table 6). Variability of nitrate and phosphorous was very high; variability of the $\mathrm{C} / \mathrm{N}$ ratio, $\mathrm{pH}$, and soil temperature was very low; the other environmental variables showed intermediate variability (Table 6).

We assessed the relationships between the variation of traits (CV-traits) and of the environmental factors (CV-environmental parameter) emerging as the most influential based on results of linear regression and hierarchical variance partitioning (Table 5, online resource ESM 3). As the variable soil temperature showed a very low variation (Table 6, online resource ESM 2) it was not considered. Consequently, CV-CV graphs are displayed for light, nitrate $\left(\mathrm{NO}_{3}\right)$, ammonium $\left(\mathrm{NH}_{4}\right)$, magnesium $(\mathrm{P})$ and potassium $(\mathrm{K})$ which exhibited 
intermediate to high variation (Fig. 1). From the $\mathrm{CV}$-traits to $\mathrm{CV}$-environment comparison (Fig. 1) it appears that the variable traits SLA, LDMC, and height growth have CV values that are similar to or smaller than the $\mathrm{CV}$ values of the environmental factors. The highly variable clonal traits, by contrast, appear to have largely higher $\mathrm{CV}$ values than the related environmental factors.

354

355

356

357

358

359

360

\section{Discussion}

In our study, significant intraspecific differences in plant functional traits between the contrasting habitats indicate phenotypic functional adaptation to in situ environmental conditions, supporting hypothesis $\mathrm{H} 1$ for all traits investigated. While species adapted their trait attributes between the two habitats in the same way, they showed species-specific responses to environmental factors within habitats. Environmental differences within habitats were less pronounced. However, soil temperature, light, nitrate, ammonium, magnesium and potassium emerged to be important drivers of intraspecific trait-environment relationships even at the scale of few meters. Leaf traits, horizontal stem length and clonal traits responded significantly positively or negatively to the availability of nutrients, while plant height responded negatively to soil temperature and positively to light availability, supporting $\mathrm{H} 2$ for these traits. The variation of leaf traits and plant height was lower than the environmental variation indicating that those traits are more regulated by the plant than clonal traits. The latter, i.e. horizontal stem length, number of bifurcations/nodes and distance between bifurcations/nodes, exhibited much larger trait variation than environmental variation. According to Grassein et al. (2010, see review of Schellenberg and Pontes (2012)) species strategy is defined by both trait values and trait plasticity. Our findings confirm to some extent the conclusions of Grassein et al. (2010) on LDMC as we found the same trait to be controlled compared to other traits. However, in our study, the plasticity of this trait was still high enough to enable adjustment to environmental factors. Our findings encourage investigating trait control at the intraspecific level.

In more detail, our results show that SLA and plant height are not only characterized by considerable variation between communities and species, as already assessed (Westoby 1998; Grime 2002; Poorter et al. 2006; Pierce et al. 2007), but that ecologically significant variation is also occurring at the intraspecific level (Tables 4, 5). In line with our results, Wilson et al. (1999) found in a survey of 769 herbaceous species of the British flora that SLA exhibits strong variation within populations. With respect to phenotypic adaptation, all four study species showed significantly higher values of SLA and significantly higher height (with the exception of height variation in T. longicaulis) in the north-exposed habitat. Our findings support the view that higher plant height and higher SLA in the species in the north-exposed habitat might be related to the significantly higher availability of all investigated nutrients $(\mathrm{P}$, $\mathrm{K}, \mathrm{Mg}, \mathrm{NH}_{4}, \mathrm{NO}_{3}$ ) along with higher soil moisture and conductivity. Within the south-facing habitat, the SLA proved to be significantly positively influenced by nitrate availability in $A$. sempervirens (Table 5). This finding is in line with experimental results of Al Haj Khaled et al. (2005) which demonstrated that nitrogen availability positively affects SLA attributes within species.

Literature evidence points out that high SLA values are positively correlated with rapid leaf turnover, potential relative growth rate and photosynthetic efficiency (Cornelissen et al. 2003; Kleyer et al. 2008); fast turnover of plant parts allows also a more flexible response to the spatial patchiness of light availability (Grime 1994), which is a characteristic of the habitat on the north-facing slope for all species (except T. longicaulis). The higher 
density of the canopy in this habitat causes competition for light, which might modulate light availability giving advantage in having a higher SLA.

With respect to the second investigated leaf trait, i.e. the leaf dry matter content (LDMC) we found the inverse response as SLA (Table 4). The LDMC was significantly higher in the south-facing habitat for all species (with the exception of $T$. longicaulis whose higher values were not significant). The LDMC of this species, however, showed variation in response to variation in magnesium and potassium availability within the north-facing habitat (Table 5). High values of LDMC correspond to a low turnover rate (Cornelissen et al. 2003; Kleyer et al. 2008) and thicker leaves, better withstanding physical constraints. Both characteristics help to store nutrients, representing a big advantage in unproductive environments (Ryser and Urbas 2000) such as the south-facing slope. Following Gross et al. (2007), this trait appears to be a better predictor for plant responses to nutrient stress than SLA. Earlier literature confirms that LDMC is less variable than SLA (Garnier et al. 2001) which is confirmed by our data showing lower intraspecific and interspecific variation (CV) of LDMC.

The second investigated whole-plant trait, i.e. horizontal stem length of clonal species, responded in the same way to the differentiated environmental conditions than plant height. Horizontal stem length represents the diameter of individuals and thus their maximum range of space occupancy. All investigated species showed significantly higher space occupancy in the north-facing habitat (Table 4). These data were not sampled for A. sempervirens, but this is the species with the longest horizontal stems of all examined species. Due to this, it exhibits a much higher capacity of space occupancy in the $\mathrm{N}$-facing habitat (several meters long) compared to the $\mathrm{S}$-facing ones (shorter than $1 \mathrm{~m}$ ). The results of all study species might be explained by two mechanisms. First, the higher availability of nutrients and water allowing for higher growth potential and second, the space-occupancy advantage under competitive conditions with lower light availability. This is in line with the findings of Tissue and Nobel (1988) and Grime (2002) who state that in a dense community, the horizontal stem length provides higher ability to explore new space, increasing the possibility to exploit new resources and to allocate them within the organism.

Both clonal traits 'number of bifurcations/nodes per cm' and 'distance between bifurcations/nodes' showed the highest variation in all study species. This might to some extent be fostered by the high variation of light-, water- and nutrient-availability within habitats. Apart from being an alternative to sexual reproduction, clonality allows rapid colonization of open habitats, pre-emptive occupation of space by forming dense patches, avoidance of competition implicit in fugitive growth and better foraging for resources in a heterogeneous soil matrix (Stöcklin1992; Oborny and Bartha 1995).

In both investigated clonal traits, phenotypic adaptation to the contrasting environmental conditions of the north- and south-facing slope were found only in S. nitida. This dominant grass showed a higher capacity of multiplication (number of bifurcations) at the south-facing slope but higher capacity of space occupancy (distance between bifurcations) at the north-facing slope. The space occupancy might be confined by the lower nutrient and moisture availability of the habitat $S$ while higher availability of these resources allows for higher general growth capacity, which is reflected also in the horizontal stem length. This trait of $S$. nitida was significantly positively influenced by an increased availability of magnesium within the north-facing habitat. Within this habitat, T. longicaulis was seen to produce fewer nodes but longer internodal stem-segments with higher nutrient availability while higher light availability led to the production of more nodes.

In our study, the seed mass showed significant intraspecific differences between the two contrasting habitats. This is surprising because seed mass differences were found to be 
often conservative between genera or families (Hodgson and Mackey1986; Mazer 1989; Peat and Fitter1994; Westoby 1998).

Our results confirm phenotypic adaptation of seed mass in all tested species. Their seed mass was significantly higher in the south-facing habitat compared to the north-facing one. As summarized by Pakeman et al. (2008), it has been shown that larger seeds offer an advantage (e.g. Buckley 1982) or are more common in drier environmental conditions (Wright and Westoby 1999), since the seedlings of larger seeds better withstand environmental hazards being reserves needed for drought-resistance mechanisms (Leishman and Westoby 1994). However, Pakeman et al. (2008) found substantially more evidence that seed size was higher at warmer sites. The significant differences found in our study are possibly related to differences in both, temperature and water availability. However, lower competition in the south-facing habitat might foster a higher investment in sexual reproduction. The north-facing habitat, in contrast, exhibits higher levels of competition since $S$. nitida forms an extraordinarily dense vegetation carpet.

Despite the fact that germination rate observed in our study was very low, the results on the intraspecific differences of the germination rate also support our findings on seed mass. Significantly higher intraspecific germination rate of seeds produced by plants in the southexposed habitat are possibly linked to the higher seed mass of these seeds. Thus, the production of larger seeds in the stressful south-facing habitat provides more reserves for germination, in agreement with the advantages of larger seeds reported by Westoby et al. (2002) and the subsequent higher survival rates of seedlings (Moles and Westoby 2006), especially under various hazards including drought (Westoby 1998).

The range of trait variation is the result of the plants trial to reach equilibrium between costs and benefits as the strategy of each plant individual is the best possible compromise within a given environment (Reich et al. 2003). In other words, the advantage provided by phenotypic plasticity per se, allows for adaptation to environmental conditions.

In all four species, the individuals of the south-facing habitat are better equipped to cope with environmental stress. In fact they are characterized by lower plant height, slower growing rate, thicker laminas, higher tissue density, lower photosynthetic efficiency, longer leaf life span (and lower leaf turnover), more investment in structural strength, and higher investment in seeds (stored energy) which ensure future successful performance of seed-lings under stressful conditions.

Data limitation

Both investigated habitats, i.e. the south- and north-facing slope, very likely have differences in their disturbance history. Due to local topography, grazing animals had more easily access to the south-facing slope before the closure of the reserve in 1970. This might explain in concert with the stressful environmental conditions that some of the late-successional plant species as A. sempervirens in the vegetation of the south-facing slope might have lower age. Plant age might influence the performances of some of the examined traits, mainly when it affects capacity of nutrient and water uptake by plant size and rooting depth. This might be the case for A. sempervirens, which is younger in the south- than in the north-facing slope. One representative individual of the south-facing slope was analyzed by dwarf shrub chronology and appeared to be 20 years old. One of the largest individuals on the north-facing slope was estimated according to annual increment of horizontal stem length and is around 60 years old. In case of $S$. nitida no differences appear with age since the species does not develop huge individuals because clonal offspring disintegrate after some years. In case of $L$. corniculatus and T. longicaulis, both of which are larger and therefore probably older on the south-facing slope, we were able to adjust the testing for trait differences between habitats for 
plant size (biomass) in all traits (see McCarthy and Enquist 2007) except seed traits.

498 However, results were largely the same when testing for apparent plasticity, i.e. without

499 adjusting for plant size which in turn relativizes the above stressed argumentation on the

500 potential impact of plant size on phenotypic trait adaptation. extension each) and could not include further spatial replicates, i.e. further valleys with northand south-facing grasslands in this highly labour-intensive work. This limits the strength of conclusions drawn to the global change level and we suggest further studies in order to shed more light on the evidence indicated in our study.

Implications for global change and nature conservation

Our findings demonstrate phenotypic differentiation of species at medium spatial scales, i.e. $200 \mathrm{~m}$ air distance between the opposing slopes of a valley. Some species even vary their traits according to the fine scale (i.e. centimeters to meters) heterogeneity in temperature. The existing medium-scale climatic differences between the contrasting slopes, manifesting e.g. in a difference of $8^{\circ} \mathrm{C}$ in the soil temperature, are larger than the overall climatic shifts predicted by coarse-scale scenarios (IPCC 2012) and partly cover the magnitude of European extreme events such as mega-heatwaves (Barriopedro et al. 2011). Therefore, we expect that these species can be pre-adapted (to some degree) to the overall expected environmental changes. Studying medium- and fine-scale intraspecific trait variability helps to quantify the magnitude of plasticity that can serve as adaptive potential of plant species.

Switching the focus on land-use change, the abandonment of traditional grazing regimes in the study area resulted in succession and subsequent increase in competition in the climatically and edaphically favorable north-facing slope. The related differences in nutrient availability at medium and fine spatial scales resulted in an adjustment of functional traits, e.g. SLA and LDMC.

As phenotypic specialization might enable a differentiated response to land-use and climate change it ultimately might increase plant fitness and survival. Nature conservation should therefore protect environmental heterogeneity between and within habitats in order to maintain larger intraspecific variability and thereby a variety of phenotypic specialization that finally can buffer future environmental extremities due to climate and land-use changes. These findings might support conservation planning with information on how and where to prioritize conservation objects and how to work in situ (Beier and Brost 2010; Groves et al. 2012). This meets the purpose of moderating impacts of climate change and capitalizing on emerging opportunities, i.e. climate change adaptation (Groves et al.2012; IPCC 2012).

\section{Conclusions}

Using ca. three times larger sample size than required by the standard protocol for measuring plant traits, we show the intermediate to high degree of intraspecific variability of whole plant, clonal, leaf and seed traits. We stress the adaptive significance of the key plant traits leading to intraspecific adaptation of strategies. We argue that protecting habitats with considerable medium- and small-scale environmental heterogeneity is important to maintain large intraspecific variability within local populations that finally can buffer against uncertainty of future climate and land use scenarios. 
We thank the Analytical Chemistry of the Bayreuth Centre of Ecology and Environmental Research (BayCEER, Germany) for performing the analyses of soil chemical parameters. This research was partially supported by Montagna di Torricchio Nature Reserve. SB was supported by the Hungarian National Science Foundation (OTKA K 72561). CW was supported by the Bavarian State Ministry of Sciences, Research and the Arts within the FORKAST project. We thank Martin Hallinger (University of Greifswald, Germany) for help with the determination of age of $A$. sempervirens.

\section{References}

Ackerly DD, Cornwell WK (2007) A trait-based approach to community assembly: partitioning of species trait values into within- and among-community components. Ecol Lett 10:135-145

Albert CH, Thuiller W, Yoccoz NG, Douzet R, Aubert S, Lavorel S (2010) A multi-trait approach reveals the structure and the relative importance of intra vs. interspecific variability in plant traits. Funct Ecol 24:1192-1201

Al Haj Khaled R, Duru M, Theau JP, Plantureux S, Cruz P (2005) Variation in leaf traits through seasons and Navailability levels and its consequences for ranking grassland species. J Veg Sci 16:391-398

Badyaev AV (2009) Evolutionary significance of phenotypic accommodation in novel environments: an empirical test of the Baldwin effect. Phil Trans R Soc B 364:1125-1141

Barriopedro D, Fischer EM, Luterbacher J, Trigo RM, Garcia-Herrera R (2011) The hot summer of 2010: redrawing the temperature record map of Europe. Science 332:220-224

Barker G, Grant A, Beavitt P, Christie N, Giorgi J, Hoare P, Leggio T, Migliavacca M (1991) Ancient and Modern Pastoralism in Central Italy: an Interdisciplinary Study in the Cicolano Mountains. Papers of the British School at Rome 59:15-88

Baskin CC, Baskin JM (1998) Seeds: Ecology, biogeography, and evolution of dormancy and germination. Academic Press, San Diego

Beier P, Brost B (2010) Use of land facets to plan for climate change: conserving the arenas, not the actors. Conserv Biol 24:701-710

Bolnick DI, Svanba“ck R, Fordyce JA, Yang LH, Davis JM, Hulsey CD, Forister ML (2003) The ecology of individuals: incidence and implications of individual specialization. Am Nat 161:1-28

Bossdorf O, Richards CL, Pigliucci M (2008) Epigenetics for ecologists. Ecol Lett 11:106-115

Branch NP (2012) Early-Middle Holocene vegetation history, climate change and human activities at Lago Riane (Ligurian Apennines, NW Italy). Veg Hist Archeobot. Published online 21 November 2012

Buckley RC (1982) Seed size and seedling establishment in tropical arid dunecrest plants. Biotropica 14:314315

Burdon JJ (1987) Phenotypic and genetic patterns of resistance to the pathogen Phakopsora pachyrhizi in populations of Glycine canescens. Oecologia 73:257-267

Carter EB, Theodorou MK, Morris P (1997) Responses of Lotus corniculatus to environmental change. New Phytol 36:245-253

Cornelissen JHC, Lavorel S, Garnier E, D1'az S, Buchmann N, Gurvich DE, Reich PB, ter Steege H, Morgan HD, van der Heijden MGA, Pausas JG, Poorter H (2003) A handbook of protocols for standardised and easy measurement of plant functional traits worldwide; in. Aust J Bot 51:335-380

Garnier E, Laurent G, Bellmann A, Debain S, Berthelier P, Ducout B, Roumet C, Navas ML (2001) Consistency of species ranking based on functional leaf traits. New Phytol 152:69-83

Garnier E, Cortez J, Billes G, Navas ML, Roumet C, Debussche M, Laurent G, Blanchard A, Aubry D, Bellmann A, Neill C, Toussaint JP (2004) Plant functional markers capture ecosystem properties during secondary succession. Ecology 85:2630-2637

Grassein F, Till-Bottraud I, Lavorel S (2010) Plant resource-use strategies: the importance of phenotypic plasticity in response to a productivity gradient for two subalpine species. Ann Bot 106:637-645

Grime JP (1994) The role of plasticity in exploiting environmental heterogeneity. In: Caldwell MM, Pearcy R (eds) Exploitation of Environmental Heterogeneity in Plants. Academic press, San Diego, pp 1-18 
Grime JP (2002) Plant strategies, vegetation processes, and ecosystem properties, 2nd edn. Wiley, Chichester

Gross N, Suding KN, Lavorel S (2007) Leaf dry matter content and lateral spread predict response to land use change for six subalpine grassland species. J Veg Sci 18:289-300

601

602

603

604

605

606

607

608

609

610

611

612

613

614

615

616

617

618

619

620

621

622

623

624 J, Marshall R, Popper K, Schill S, Shafer SL (2012) Incorporating climate change into systematic conservation planning. Biodivers Conserv 21:1651-1671

Grömping U (2006) Relative importance for linear regression in R: the package relaimpo. J Stat Softw 17:1-27

Halassy M, Campetella G, Canullo R, Mucina L (2005) Patterns of functional clonal traits and clonal growth modes in contrasting grasslands in the central Apennines, Italy. J Veg Sci 16:29-36

Hodgson JG, Mackey JML (1986) The ecological specialisation of dicotyledonous families within a local flora: some factors constraining optimization of seed size and their evolutionary significance. NewPhytol $12: 497-515$

Hoffmann G (1991) Die Untersuchung von Bo“den - Methodenbuch 1. VDLUFA-Verlag, Darmstadt

Hulshof CM, Swenson NG (2010) Variation in leaf functional trait values within and across individuals and species: an example from a Costa Rican dry forest. Funct Ecol 24:217-223

IPCC (2012) Managing the risks of extreme events and disasters to advance climate change adaptation. A special report of working Groups I and II of the intergovernmental panel on climate change. In: Field CB, Barros V, Stocker TF et al (eds) Cambridge University Press, Cambridge, UK, and New York, NY, USA, 582 pp

ISTA (International Society of Testing Analysis) (1999) International rules for seed testing. Seed Sci Technol 27(supplement):201-244

Kleyer M, Bekker RM, Knevel IC, Bakker JP, Thompson K, Sonnenschein M, Poschlod P, van Groenendael JM, Klimes L, Klimesová J, Klotz S, Rusch GM, Hermy M, Adriaens D, Boedeltje G, Bossuyt B, Endels P, Götzenberger L, Hodgson JG, Jackel A-K, Dannemann A, Ku “hn I, Kunzmann D, Ozinga WA, Römermann C, Stadler M, Schlegelmilch J, Steendam HJ, Tackenberg O, Wilmann B, Corne-lissen JHC, Eriksson O, Garnier E, Fitter A, Peco B (2008) The LEDA Traitbase: a database of plant life-history traits of North West European Flora. J Ecol 96:1266-1274

Klimešová J, Klimeš L (2006) CLO-PLA3: a database of clonal growth architecture of Central-European plants.http://clopla.butbn.cas.cz

Knevel IC, Bekker RM, Kunzmann D, Stadler M, Thompson K (2005) The LEDA Traitbase collecting and measuring standards of life-history traits of the NW European flora. Published by the University of Groningen, Groningen

Kwiatkowski W, Venanzoni R (1994) Carta dei suoli della riserva naturale di Torricchio. La Riserva Naturale di Torricchio 9:15-21

Leishman MR, Westoby M (1994) The role of seed size in seedling establishment in dry soil conditions experimental evidence from semi-arid species. J Ecol 82:249-258

Lemke I, Kolb A, Diekmann M (2012) Region and site conditions affect phenotypic trait variation in five forest herbs. Acta Oecol 39:18-24

Linhart YB (1988) Intra-population differentiation in annual plants. III. The contrasting effects of intra- and inter-specific competition. Evolution 42:1047-1064

Linhart YB, Grant MC (1996) Evolutionary significance of local genetic differentiation in plants. Annu Rev Ecol Syst 27:237-277

Mawdsley JR, O’Malley R, Ojima DS (2009) A Review of climate-change adaptation strategies for wildlife management and biodiversity conservation. Conserv Biol 2:1080-1089

Maillette C (1992) Seasonal model of modular growth in plants. J Ecol 80:123-130

Mazer SJ (1989) Ecological, taxonomic and life history correlates of seed mass among Indiana Dune angiosperms. Ecol Monogr 59:153-175

McCarthy MC, Enquist BJ (2007) Consistency between an allometric approach and optimal partitioning theory in global patterns of plant biomass allocation. Funct Ecol 21:713-720

Miner BG, Sultan SE, Morgan SG, Padilla DK, Relyea RA (2005) Ecological consequences of phenotypic plasticity. Trends Ecol Evol 20(12):685-692

Moles AT, Westoby M (2006) Seed size and plant strategy across the whole life cycle. Oikos 113:91-105

Murray K, Conner MM (2009) Methods to quantify variable importance: implications for the analysis of noisy ecological data. Ecology 90:348-355

Nicotra AB, Atkin OK, Bonser SP, Davidson AM, Finnegan EJ, Mathesius U, Poot P, Purugganan MD, Richards CL, Valladares F, van Kleunen M (2010) Plant phenotypic plasticity in a changing climate.

Trends Plant Sci 15:684-992

Oborny B, Bartha S (1995) Clonality in plant communities - An overview. Abstracta Botanica 19:115-127 
655

656

657

658

659

660

661

662

663

664

665

666

667

668

669

670

671

672

673

674

675

676

677

678

679

680

681

682

683

684

685

686

687

688

689

690

691

692

693

694

695

696

697

698

699

700

701

702

703

704

705

706

707

708

709

710

711

712

713

714

Pakeman RJ, Garnier E, Lavorel S, Ansquer P, Castro H, Cruz P, Dolezal J, Eriksson O, Freitas H, Golodet C, Kigel J, Kleyer M, Leps J, Meier T, Papadimitriou M, Papanastasi VP, Quested H, Quetier F, Rusch G, Sternberg M, Theau JP, Thebault A, Vile D (2008) Impact of abundance weighting on the responseof seed traits to climate and land use. J Ecol 96:355-366

Peat HJ, Fitter AH (1994) Comparative analyses of ecological characteristics of British angiosperms. Biol Rev 69:95-115

Pierce S, Luzzaro A, Caccianiga M, Ceriani RM, Cerabolini B (2007) Disturbance is the principala-scale filter determining niche differentiation, coexistence and biodiversity in an alpine community. J Ecol 95:698706

Pignatti S (1982) Flora d'Italia. Edagricole, Bologna

Poorter H, Pepin S, Rijkers T, De Jong Y, Evans JR, Körner C (2006) Construction costs, chemical composition, and payback time of high and low irradiance leaves. J Exp Bot 57:355-371

Poorter H, Niinemets Ü, Poorter L, Wright IJ, Villar R (2009) Causes and consequences of variation in leaf mass per area (LMA): a meta-analysis. New Phytol 182:565-588

R Development Core Team (2010) R: A language and environment for statistical computing. R version 2.13.1. Foundation for Statistical Computing. Vienna, Austria, http://www.R-project.org

Reich PB, Wright IJ, Cavender-Bares J, Craine JM, Oleksyn J, Westoby M, Walters MB (2003) The evolution of plant functional variation: traits, spectra and strategies. Int J Plant Sci 164:S143-S164

Ryser P, Urbas P (2000) Ecological significance of leaf life span among Central European grass species. Oikos 91:41-50

Schellenberg J, Pontes S (2012) Plant functional traits and nutrient gradients on grassland. Grass Forage Sci 67:305-319

Silvertown J (2004) Plant coexistence and the niche. Trends Ecol Evol 19:605-611

Simms EL (1990) Examining selection on the multivariate phenotype: plant resistance to herbivores. Evolution 44:1177-1188

Stanton ML (1984) Seed variation in wild radish: effect of seed size on components of seedlings and adult fitness. Ecology 65:1105-1112

Stöcklin J (1992) Umwelt, Morphologie und Wachstumsmuster klonaler Pflanzen - eine Übersicht. Bot Helv $102: 3-21$

Sultan SE (1987) Evolutionary implications of phenotypic plasticity in plants. In: Hecht MK, Wallace B, Prance GT (eds) Evolutionary Biology, Vol 21. Springer, New York, pp 127-178

Tissue DT, Nobel PS (1988) Parent-ramet connections in Agave desert: influences of carbohydrates on growth. Oecologia 75:266-271

Turkington R (1989) The growth, distribution, and neighbour relationships of Trifolium repens in a permanent pasture. V. The coevolution of competitors. J Ecol 77:717-733

Turkington R, Aarssen LW (1984) In: Dirzo R, Sarukhan J (eds) Local scale differentiation as a result of competitive interactions. Sunderland, MA, Perspectives in Plant Population Ecology. Sinauer, pp 107-127

Venanzoni R, Kwiatkowski W (1995) Analisi integrata del paesaggio in un settore dell'Appennino Centrale (Riserva naturale Montagna di Torricchio). Colloq Phytosociol 24:187-201

Violle C, Enquist BJ, McGill BJ, Jiang L, Albert CH, Hulshof C, Jung V, Messier J (2012) The return of the variance: intraspecific variability in community ecology. Trends Ecol Evol 27(4):244-252

Walck JL, Hidayati SN, Dixon KW, Thompson K, Poschlod P (2011) Climate change and plant regeneration from seed. Glob Change Biol 17:2145-2161

Webb CT, Hoeting JA, Ames GM, Pyne MI, Poff NL (2010) A structured and dynamic framework to advance traits-based theory and prediction in ecology. Ecol Lett 13:267-283

Wellstein C (2012) Seed-litter-position drives seedling establishment in grassland species under recurrent drought. Plant Biol 14:1006-1010

Wellstein C, Kuss P (2011) Diversity and frequency of clonal traits along natural and land-use gradients in grasslands of the Swiss Alps. Folia Geobot 46:255-270

Wellstein C, Schröder B, Reineking B, Zimmermann NE (2011) Understanding species and community response to environmental change - A functional trait perspective. Agr Ecosyst Environ 145:1-4

West-Eberhard MJ (2005) Phenotypic accommodation: adaptive innovation due to developmental plasticity. J Exp Zool B 304:610-618

Westoby M (1998) A leaf-height-seed (LHS) plant ecology strategy scheme. Plant Soil 199:213-227

Westoby M, Falster DS, Moles AT, Vesk PA, Wright IJ (2002) Plant ecological strategies: some leading dimensions of variation between species. Annu Rev Ecol Syst 33:125-159

Wilson PJ, Thompson K, Hodgson JG (1999) Specific Leaf Area and Leaf Dry Matter Content as Alter-native predictors of Plant Strategies. New Phytol 143:155-162

Wright IJ, Westoby M (1999) Differences in seedling growth behaviour among species: trait correlations across species, and trait shifts along nutrient compared to rainfall gradients. J Ecol 87:85-97 
Table 1 Geo-physical and plant-sociological characteristics of the sampling sites (i.e. habitats)

\begin{tabular}{lll}
\hline & Site N & Site S \\
\hline Coordinates & $42^{\circ} 57^{\prime} 21.8^{\prime \prime} \mathrm{N}-13^{\circ} 01^{\prime} 10.1^{\prime \prime} \mathrm{E}$ & $42^{\circ} 57^{\prime} 35.1^{\prime \prime} \mathrm{N}-13^{\circ} 01^{\prime} 07.4^{\prime \prime} \mathrm{E}$ \\
Elevation (m) & 1200 & 1165 \\
Exposition & $320^{\circ} \mathrm{N}-\mathrm{NW}$ & $140^{\circ} \mathrm{S}-\mathrm{SE}$ \\
Slope $\left(^{\circ}\right)$ & 35 & 17 \\
Soil & Rendzina on limestone & Lithosols and regosols, highly eroded soil \\
Vegetation & Sesleria nitidae-Brometum erecti & Asperulo purpureae-Brometum erecti \\
Series & Montane calcicolous Fagus sylvatica series & Montane calcicolous Ostrya carpinifolia \\
& & series on steep rocky slopes
\end{tabular}

Both associations belong to the order Brometalia erecti W. Koch 1926, class Festuco-Brometea Br.-Bl. et Tx. in Br.-Bl. 1949 
Table 2 Traits definitions, respective life-history processes, and functional information from literature

\begin{tabular}{|c|c|c|c|c|c|}
\hline & $\begin{array}{l}\text { Life-history } \\
\text { processes }\end{array}$ & $\begin{array}{l}\text { Trait- } \\
\text { environment } \\
\text { links }\end{array}$ & Definition & Functional significance & Literature \\
\hline \multicolumn{6}{|l|}{ Leaf traits } \\
\hline SLA & $\begin{array}{l}\text { Establishment; } \\
\text { competition }\end{array}$ & $\begin{array}{l}\text { Light; } \\
\text { moisture, } \\
\text { nutrients; } \\
\text { temperature }\end{array}$ & $\begin{array}{l}\text { The ratio of fresh leaf } \\
\text { area to leaf dry mass }\end{array}$ & $\begin{array}{l}\text { Positively correlated with potential relative growth } \\
\text { rate and mass-based maximum photosynthetic rate; } \\
\text { the relationships between SLA and light condition, } \\
\text { leaf defence structures and environmental stresses } \\
\text { are well known. Plasticity of SLA is well } \\
\text { documented }\end{array}$ & $\begin{array}{l}\text { Kleyer et al. (2008); Poorter et al. } \\
\text { (2006); Cornelissen et al. } \\
\text { (2003); Wilson et al. (1999); } \\
\text { Westoby (1998) }\end{array}$ \\
\hline LDMC & $\begin{array}{l}\text { Establishment; } \\
\text { competition }\end{array}$ & $\begin{array}{l}\text { Nutrients; } \\
\text { temperature }\end{array}$ & $\begin{array}{l}\text { The ratio of dry leaf mass } \\
\text { to fresh leaf mass }\end{array}$ & $\begin{array}{l}\text { Used as a measure of leaf tissues density, which plays } \\
\text { a central role in the use of nutrients by the species, } \\
\text { determining the rate of turnover of biomass. At high } \\
\text { values of LDMC, the rate of potential growth is low } \\
\text { and the leaves tend to have a low turn-over to } \\
\text { conserve nutrients, a big advantage in unproductive } \\
\text { environments }\end{array}$ & $\begin{array}{l}\text { Cornelissen et al. (2003); Kleyer } \\
\text { et al. (2008); Ryser and Urbas } \\
\text { (2000); Gross et al. (2007) }\end{array}$ \\
\hline \multicolumn{6}{|c|}{ Whole plant traits } \\
\hline Plant height & Competition & $\begin{array}{l}\text { Nutrients; } \\
\text { moisture; } \\
\text { temperature }\end{array}$ & $\begin{array}{l}\text { The distance between the } \\
\text { highest photosynthetic } \\
\text { tissues and the base of } \\
\text { the plant }\end{array}$ & $\begin{array}{l}\text { Associated with competitive vigour, whole plant } \\
\text { fecundity and generation time after disturbance, } \\
\text { There are also important trade-offs between plant } \\
\text { height and tolerance or avoidance of environmental } \\
\text { stress }\end{array}$ & $\begin{array}{l}\text { Kleyer et al. (2008); Cornelissen } \\
\text { et al. (2003); Westoby (1998) }\end{array}$ \\
\hline $\begin{array}{l}\text { Horizontal } \\
\text { stem length }\end{array}$ & Competition & $\begin{array}{l}\text { Light; } \\
\text { nutrients; } \\
\text { moisture; } \\
\text { temperature }\end{array}$ & $\begin{array}{l}\text { Maximum length of the } \\
\text { horizontal stems of the } \\
\text { plant }\end{array}$ & $\begin{array}{l}\text { A measure of the maximum range of space occupancy. } \\
\text { Lateral spread of horizontal stems enables the plant } \\
\text { to place photosynthetic and reproductive organs at } \\
\text { the microscale to new environments. This might help } \\
\text { to minimize competition. Additionally, maximal } \\
\text { lateral spread of sexual and vegetative reproduction } \\
\text { is associated with increasing distribution of new } \\
\text { individuals }\end{array}$ & $\begin{array}{l}\text { Silvertown (2004); Klimešová } \\
\text { and Klimeš (2006) }\end{array}$ \\
\hline
\end{tabular}


Table 2 continued

\begin{tabular}{|c|c|c|c|c|c|}
\hline & $\begin{array}{l}\text { Life-history } \\
\text { processes }\end{array}$ & $\begin{array}{l}\text { Trait- } \\
\text { environment } \\
\text { links }\end{array}$ & Definition & Functional significance & Literature \\
\hline \multicolumn{6}{|l|}{ Clonal traits } \\
\hline $\begin{array}{l}\text { No. of } \\
\text { bifurcations/ } \\
\text { nodes per } \\
\mathrm{cm}\end{array}$ & $\begin{array}{l}\text { Competition; } \\
\text { regeneration }\end{array}$ & $\begin{array}{l}\text { Nutrients; } \\
\text { moisture; } \\
\text { temperature }\end{array}$ & $\begin{array}{l}\text { No. of bifurcations or } \\
\text { nodes per cm of a plants } \\
\text { stem }\end{array}$ & $\begin{array}{l}\text { A measure of the multiplication capacity which is } \\
\text { associated with the abundance of space occupancy, } \\
\text { i.e. density/packing of individuals/ramets }\end{array}$ & $\begin{array}{l}\text { Knevel et al. (2005); Maillette } \\
\text { (1992) }\end{array}$ \\
\hline $\begin{array}{l}\text { Distance } \\
\text { between } \\
\text { bifurcations/ } \\
\text { nodes }\end{array}$ & $\begin{array}{l}\text { Competition; } \\
\text { regeneration }\end{array}$ & $\begin{array}{l}\text { Light; } \\
\text { nutrients; } \\
\text { moisture; } \\
\text { temperature }\end{array}$ & $\begin{array}{l}\text { Distance between the } \\
\text { bifurcations or nodes of } \\
\text { a plants stem }\end{array}$ & $\begin{array}{l}\text { A measure of the capacity of space occupancy by } \\
\text { clonal growth. Lateral spread enables the plant to } \\
\text { colonize a new substrate and avoid intraspecific } \\
\text { competition. Limited lateral spread could be } \\
\text { expected in situations where facilitation is important }\end{array}$ & Klimešová and Klimeš (2006) \\
\hline \multicolumn{6}{|l|}{ Seed traits } \\
\hline Seed mass & $\begin{array}{l}\text { Establishment; } \\
\text { dispersal }\end{array}$ & $\begin{array}{l}\text { Moisture; } \\
\text { nutrients; } \\
\text { temperature }\end{array}$ & $\begin{array}{l}\text { The air dried weight of } \\
\text { seeds }\end{array}$ & $\begin{array}{l}\text { Resources stored in large seeds help the young } \\
\text { seedling to survive and establish in the face of } \\
\text { environmental hazards. Connection with dispersion } \\
\text { and persistence in the soil }\end{array}$ & $\begin{array}{l}\text { Kleyer et al. (2008); Cornelissen } \\
\text { et al. (2003); Westoby (1998); } \\
\text { Westoby et al. (2002). }\end{array}$ \\
\hline $\begin{array}{l}\text { Seed } \\
\text { germination }\end{array}$ & Establishment & $\begin{array}{l}\text { Moisture; } \\
\text { temperature }\end{array}$ & $\begin{array}{l}\text { The percentage of seeds } \\
\text { germinated under } \\
\text { defined environmental } \\
\text { conditions }\end{array}$ & $\begin{array}{l}\text { Strongly associated with species ecology and } \\
\text { competition. The relative performance of individual } \\
\text { plants during the early stages of life, i.e. germination } \\
\text { and seedlings establishment, can have important } \\
\text { effects on subsequent adult growth and fitness }\end{array}$ & $\begin{array}{l}\text { Baskin and Baskin (1998); } \\
\text { Stanton (1984); Walck et al. } \\
\text { (2011); Wellstein (2012) }\end{array}$ \\
\hline
\end{tabular}


Table 3 Differences of environmental variables at the place of growth of individuals between species and sites (i.e. habitats)

\begin{tabular}{|c|c|c|c|c|c|c|c|}
\hline \multirow{4}{*}{$\begin{array}{l}\text { Place of growth of } \\
\text { individuals of respective } \\
\text { species } \\
\text { Environmental variables } \\
\text { and resources }\end{array}$} & \multirow{4}{*}{$\begin{array}{l}\text { Site } \mathrm{N}+\mathrm{S} \\
\text { All species } \\
\text { Mean and SD }\end{array}$} & \multicolumn{2}{|l|}{ Main effect of site } & \multicolumn{4}{|c|}{ Main effect of species' place of growth } \\
\hline & & Site $\mathrm{N}$ & Site $\mathbf{S}$ & \multicolumn{4}{|l|}{ Site $\mathrm{N}+\mathrm{S}$} \\
\hline & & \multicolumn{2}{|l|}{ All species } & \multirow{2}{*}{$\begin{array}{l}\text { Sesleria nitida } \\
\text { Mean and SD }\end{array}$} & \multirow{2}{*}{$\begin{array}{l}\text { Lotus corniculatus } \\
\text { Mean and SD }\end{array}$} & \multirow{2}{*}{$\begin{array}{l}\text { Astragalus } \\
\text { sempervirens } \\
\text { Mean and SD }\end{array}$} & \multirow{2}{*}{$\begin{array}{l}\text { Thymus } \\
\text { longicaulis } \\
\text { Mean and SD }\end{array}$} \\
\hline & & Mean and SD & Mean and SD & & & & \\
\hline Light-PAR (\%) & $74.69 \pm 25.72$ & $65.85 \pm 30.38$ a & $83.52 \pm 15.78 \mathbf{b}$ & $48.10 \pm 20.33 b$ & $86.59 \pm 21.73 \mathrm{a}$ & $74.17 \pm 24.78 c$ & $90.08 \pm 8.65$ a \\
\hline Soil temperature $\left({ }^{\circ} \mathrm{C}\right)$ & $18.59 \pm 4.94$ & $14.62 \pm 1.74 \mathrm{a}$ & $22.66 \pm 3.68 \mathrm{~b}$ & $15.08 \pm 2.58 \mathrm{c}$ & $18.58 \pm 4.70 \mathrm{a}$ & $18.74 \pm 4.53 \mathrm{a}$ & $21.97 \pm 5.05 \mathbf{b}$ \\
\hline Soil moisture (\%) & $10.98 \pm 6.46$ & $12.55 \pm 6.84 \mathrm{a}$ & $9.37 \pm 5.63 \mathbf{b}$ & $14.66 \pm 4.81 \mathrm{a}$ & $13.68 \pm 5.79 \mathrm{a}$ & $13.13 \pm 3.22 \mathrm{a}$ & $2.41 \pm 2.26 \mathbf{b}$ \\
\hline $\mathrm{pH}$ & $6.67 \pm 0.41$ & $6.60 \pm 0.50 \mathrm{a}$ & $6.95 \pm 0.14 \mathrm{~b}$ & $6.90 \pm 0.31 \mathrm{~b}$ & $6.74 \pm 0.60$ ab & $6.72 \pm 0.32 \mathrm{a}$ & $6.73 \pm 0.31 \mathbf{a}$ \\
\hline Conductivity $(\mu \mathrm{S} / \mathrm{cm})$ & $195.69 \pm 61.72$ & $220.84 \pm 64.62$ a & $169.69 \pm 46.05$ b & $203.20 \pm 60.94 \mathrm{~ns}$ & $182.06 \pm 54.37 \mathrm{~ns}$ & $197.14 \pm 54.12$ ns & $201.22 \pm 74.52 \mathrm{~ns}$ \\
\hline $\mathrm{K}(\mathrm{mg} / 100 \mathrm{~g})$ & $7.42 \pm 3.65$ & $9.11 \pm 3.67 \mathrm{a}$ & $5.68 \pm 2.70 \mathrm{~b}$ & $7.83 \pm 3.54 \mathrm{~ns}$ & $7.10 \pm 3.18 \mathrm{~ns}$ & $7.60 \pm 4.29 \mathrm{~ns}$ & $7.20 \pm 3.60 \mathrm{~ns}$ \\
\hline $\mathrm{Mg}(\mathrm{mg} / 100 \mathrm{~g})$ & $7.56 \pm 2.30$ & $7.92 \pm 2.35 \mathrm{a}$ & $6.54 \pm 1.73 \mathbf{b}$ & $6.83 \pm 1.29 b$ & $7.49 \pm 2.20 \mathrm{ab}$ & $7.60 \pm 2.51 \mathrm{ab}$ & $8.31 \pm 2.72 \mathbf{a}$ \\
\hline $\mathrm{P}(\mathrm{mg} / 100 \mathrm{~g})$ & $0.12 \pm 0.14$ & $0.20 \pm 0.13 \mathrm{a}$ & $0.03 \pm 0.11 b$ & $0.10 \pm 0.11 \mathrm{a}$ & $0.09 \pm 0.11 \mathrm{a}$ & $0.18 \pm 0.19 \mathbf{b}$ & $0.11 \pm 0.14 \mathbf{a}$ \\
\hline $\mathrm{NH}_{4}(\mathrm{mg} / 100 \mathrm{~g})$ & $0.81 \pm 0.53$ & $1.09 \pm 0.59 \mathrm{a}$ & $0.52 \pm 0.23 \mathbf{b}$ & $0.90 \pm 0.49 \mathrm{a}$ & $0.87 \pm 0.56 \mathrm{a}$ & $0.96 \pm 0.64 \mathrm{a}$ & $0.52 \pm 0.25 \mathbf{b}$ \\
\hline $\mathrm{NO}_{3}(\mathrm{mg} / 100 \mathrm{~g})$ & $3.30 \pm 4.14$ & $4.81 \pm 4.79 \mathrm{a}$ & $1.74 \pm 2.54 \mathbf{b}$ & $6.01 \pm 4.33 \mathrm{c}$ & $4.25 \pm 5.41 \mathbf{b}$ & $2.19 \pm 1.94 \mathrm{~b}$ & $0.72 \pm 0.48 \mathbf{a}$ \\
\hline $\mathrm{C} / \mathrm{N}(\%)$ & $10.81 \pm 0.78$ & $11.27 \pm 0.57 \mathbf{a}$ & $10.33 \pm 0.67 \mathbf{b}$ & $10.96 \pm 0.57 \mathbf{a}$ & $10.78 \pm 0.59 \mathrm{ab}$ & $10.54 \pm 0.77 \mathbf{b}$ & $10.95 \pm 1.04 \mathrm{a}$ \\
\hline \multicolumn{8}{|c|}{ Interaction of site and species' place of growth } \\
\hline \multicolumn{2}{|l|}{$\begin{array}{l}\text { Site } \mathrm{N} \\
\text { Sesleria nitida }\end{array}$} & \multicolumn{2}{|l|}{$\begin{array}{l}\text { Site } \mathrm{N} \\
\text { Lotus corniculatus }\end{array}$} & $\begin{array}{l}\text { Site } \mathrm{N} \\
\text { Astragalus sempen }\end{array}$ & $\begin{array}{l}\text { Site } \mathrm{S} \\
\text { virens }\end{array}$ & $\begin{array}{l}\text { Site } \mathrm{N} \\
\text { Thymus longicaulis }\end{array}$ & Site S \\
\hline Mean and SD & $\mathrm{n}$ and SD & Mean and SD & Mean and SD & Mean and SD & Mean and SD & Mean and SD & Mean and SD \\
\hline $34.40 \pm 18.63 \mathbf{a}$ & $80 \pm 10.27 b$ & $80.38 \pm 27.61$ a & $93.01 \pm 10.24 b$ & $52.35 \pm 15.70 \mathrm{a}$ & $95.26 \pm 7.35$ b & $95.84 \pm 7.26 \mathbf{a}$ & $84.33 \pm 5.56 \mathbf{b}$ \\
\hline $12.60 \pm 0.28 \mathrm{a}$ & $56 \pm 0.87$ b & $14.36 \pm 0.64 \mathrm{a}$ & $23.32 \pm 1.58 \mathrm{~b}$ & $14.46 \pm 0.66 \mathrm{a}$ & $23.03 \pm 1.83 \mathbf{b}$ & $17.19 \pm 0.72 \mathbf{a}$ & $26.75 \pm 2.01 \mathrm{~b}$ \\
\hline $16.58 \pm 5.44 \mathrm{a}$ & $67 \pm 3.05 b$ & $17.56 \pm 5.05 \mathrm{a}$ & $9.63 \pm 2.66 \mathrm{~b}$ & $12.42 \pm 1.70 \mathrm{~ns}$ & $13.85 \pm 4.14 \mathrm{~ns}$ & $3.27 \pm 1.23 \mathrm{a}$ & $1.54 \pm 0.41 \mathbf{b}$ \\
\hline
\end{tabular}


Table 3 continued

\begin{tabular}{|c|c|c|c|c|c|c|c|}
\hline \multicolumn{8}{|c|}{ Interaction of site and species' place of growth } \\
\hline \multirow{2}{*}{$\begin{array}{l}\text { Site } \mathrm{N} \\
\text { Sesleria nitida } \\
\text { Mean and SD }\end{array}$} & \multirow{2}{*}{$\begin{array}{l}\text { Site S } \\
\text { Mean and SD }\end{array}$} & \multirow{2}{*}{$\begin{array}{l}\text { Site } \mathrm{N} \\
\text { Lotus corniculatus } \\
\text { Mean and } \mathrm{SD}\end{array}$} & \multirow{2}{*}{$\begin{array}{l}\text { Site S } \\
\text { Mean and SD }\end{array}$} & \multicolumn{2}{|c|}{$\begin{array}{l}\text { Site } \mathrm{N} \quad \text { Site } \mathrm{S} \\
\text { Astragalus sempervirens }\end{array}$} & \multirow{2}{*}{$\begin{array}{l}\text { Site N } \\
\text { Thymus longicaulis } \\
\text { Mean and SD }\end{array}$} & \multirow{2}{*}{$\begin{array}{l}\text { Site S } \\
\text { Mean and SD }\end{array}$} \\
\hline & & & & Mean and SD & Mean and SD & & \\
\hline $6.75 \pm 0.36 \mathrm{~ns}$ & $7.06 \pm 0.14 \mathrm{~ns}$ & $6.55 \pm 0.77 \mathrm{~ns}$ & $6.94 \pm 0.13 \mathrm{~ns}$ & $6.55 \pm 0.36 \mathrm{~ns}$ & $6.88 \pm 0.14 \mathrm{~ns}$ & $6.55 \pm 0.34 \mathrm{~ns}$ & $6.92 \pm 0.09 \mathrm{~ns}$ \\
\hline $219.07 \pm 63.81 \mathrm{~ns}$ & $186.79 \pm 54.11 \mathrm{~ns}$ & $194.18 \pm 60.98 \mathrm{~ns}$ & $168.73 \pm 43.20 \mathrm{~ns}$ & $218.52 \pm 50.04 \mathrm{a}$ & $175.76 \pm 50.13 \mathbf{b}$ & $254.17 \pm 69.76 \mathbf{a}$ & $148.27 \pm 25.13 b$ \\
\hline $9.74 \pm 3.28$ a & $5.86 \pm 2.61 \mathrm{~b}$ & $7.91 \pm 3.19 \mathrm{~ns}$ & $6.21 \pm 2.96 \mathrm{~ns}$ & $10.39 \pm 4.22 \mathrm{a}$ & $4.80 \pm 1.86 \mathbf{b}$ & $8.57 \pm 3.58$ a & $5.84 \pm 3.12$ b \\
\hline $7.46 \pm 0.93 \mathrm{~ns}$ & $6.18 \pm 1.29 \mathrm{~ns}$ & $7.87 \pm 2.56 \mathrm{~ns}$ & $7.07 \pm 1.67 \mathrm{~ns}$ & $9.17 \pm 1.97 \mathrm{a}$ & $6.03 \pm 1.98 \mathbf{b}$ & $9.77 \pm 2.76 \mathrm{a}$ & $6.86 \pm 1.76 \mathrm{~b}$ \\
\hline $0.17 \pm 0.09 \mathrm{a}$ & $0.02 \pm 0.05 \mathbf{b}$ & $0.14 \pm 0.12 \mathrm{a}$ & $0.03 \pm 0.06 \mathrm{~b}$ & $0.27 \pm 0.14 \mathrm{a}$ & $0.08 \pm 0.19 \mathbf{b}$ & $0.22 \pm 0.12 \mathbf{a}$ & $0.01 \pm 0.04 \mathbf{b}$ \\
\hline $1.17 \pm 0.54 \mathrm{~ns}$ & $0.64 \pm 0.19 \mathrm{~ns}$ & $1.18 \pm 0.62 \mathrm{~ns}$ & $0.53 \pm 0.15 \mathrm{~ns}$ & $1.35 \pm 0.64 \mathrm{~ns}$ & $0.56 \pm 0.31 \mathrm{~ns}$ & $0.68 \pm 0.25 \mathrm{~ns}$ & $0.36 \pm 0.12 \mathrm{~ns}$ \\
\hline $7.11 \pm 4.76 \mathrm{~ns}$ & $4.87 \pm 3.57 \mathrm{~ns}$ & $7.60 \pm 5.69 \mathrm{a}$ & $0.57 \pm 0.28 \mathbf{b}$ & $3.35 \pm 2.10 \mathrm{a}$ & $1.03 \pm 0.66 \mathbf{b}$ & $0.85 \pm 0.59 \mathrm{~ns}$ & $0.58 \pm 0.31 \mathrm{~ns}$ \\
\hline $11.23 \pm 0.38 \mathrm{a}$ & $10.67 \pm 0.60 \mathrm{~b}$ & $10.99 \pm 0.46 \mathrm{a}$ & $10.55 \pm 0.63 \mathbf{b}$ & $11.11 \pm 0.49 \mathrm{a}$ & $9.97 \pm 0.54 \mathbf{b}$ & $11.65 \pm 0.64 \mathrm{a}$ & $10.14 \pm 0.67 \mathbf{b}$ \\
\hline
\end{tabular}

Significant differences between species and sites were evaluated by two-way ANOVA followed by post hoc test (Tukey HSD). Main effect of site, species' place of growth, and their interaction are given subsequently. For the interaction effects, significant differences between sites are noted within species (not between species as this was not of interest). Significant differences are indicated by different lower case letters in bold; $n s$ not significant 
Table 4 Mean trait values (untransformed data) per species in each slope (N,S), and their difference $(\Delta)$

\begin{tabular}{|c|c|c|c|c|c|c|c|c|c|}
\hline & & \multicolumn{2}{|l|}{ Leaf traits } & \multicolumn{2}{|c|}{ Whole plant traits } & \multicolumn{2}{|l|}{ Clonal traits } & \multicolumn{2}{|l|}{ Seed traits } \\
\hline & & $\begin{array}{l}\text { SLA } \\
\left(\mathrm{mm}^{2} \mathrm{mg}^{-1}\right)\end{array}$ & $\begin{array}{l}\text { LDMC } \\
\left(\mathrm{mg} \mathrm{g}^{-1}\right)\end{array}$ & $\begin{array}{l}\text { Height } \\
(\mathrm{cm})\end{array}$ & $\begin{array}{l}\text { Horizontal stem } \\
\text { length }(\mathrm{cm})\end{array}$ & $\begin{array}{l}\text { No. of bifurcations/ } \\
\text { nodes per } \mathrm{cm}(n)\end{array}$ & $\begin{array}{l}\text { Distance between } \\
\text { bifurcations/nodes }(\mathrm{cm})\end{array}$ & $\begin{array}{l}\text { Seed mass } \\
(\mathrm{mg})\end{array}$ & $\begin{array}{l}\text { Seed } \\
\text { germination } \\
\text { (\%) }\end{array}$ \\
\hline \multirow[t]{3}{*}{ Sesleria nitida } & $\mathrm{N}$ & $18.04 \mathrm{a}$ & $375.03 \mathrm{a}$ & $60.33 \mathrm{a}$ & $23.35 \mathbf{a}$ & $0.09 \mathrm{a}$ & $7.93 \mathbf{a}$ & $1.80 \mathrm{a}$ & $2.00 \mathrm{a}$ \\
\hline & $\mathrm{S}$ & $15.77 \mathrm{~b}$ & $408.61 \mathrm{~b}$ & $51.00 \mathrm{~b}$ & $8.37 \mathbf{b}$ & $0.46 \mathrm{~b}$ & $2.88 \mathrm{~b}$ & $2.30 \mathrm{~b}$ & $8.00 \mathrm{~b}$ \\
\hline & $\triangle$ & 2.27 & 33.58 & 9.33 & 14.98 & 0.37 & 5.05 & 0.50 & 6.00 \\
\hline \multirow{3}{*}{$\begin{array}{l}\text { Lotus } \\
\quad \text { corniculatus }\end{array}$} & $\mathrm{N}$ & $38.43 \mathbf{a}$ & 227.47 a & $20.33 \mathbf{a}$ & $18.69 \mathrm{a}$ & 0.10 a & $1.99 \mathrm{a}$ & & \\
\hline & $\mathrm{S}$ & 24.32 b & 254.98 b & $13.10 \mathrm{~b}$ & $16.90 \mathrm{~b}$ & 0.13 a & $3.25 \mathrm{a}$ & No data & No data \\
\hline & $\Delta$ & 14.11 & 27.51 & 7.23 & 1.79 & 0.03 & 1.26 & & \\
\hline \multirow{3}{*}{$\begin{array}{l}\text { Astragalus } \\
\text { sempervirens }\end{array}$} & $\mathrm{N}$ & 17.31 a & 343.48 a & $12.80 \mathrm{a}$ & & & & $2.30 \mathrm{a}$ & $2.00 \mathrm{a}$ \\
\hline & $\mathrm{S}$ & $15.26 \mathrm{~b}$ & $371.56 \mathrm{~b}$ & $9.17 \mathrm{~b}$ & No data & Non clonal & Non clonal & $2.80 \mathrm{~b}$ & $11.00 \mathrm{~b}$ \\
\hline & $\triangle$ & 2.05 & 28.08 & 3.63 & & & & 0.30 & 9.00 \\
\hline \multirow{3}{*}{$\begin{array}{l}\text { Thymus } \\
\text { longicaulis }\end{array}$} & $\mathrm{N}$ & $14.44 \mathbf{a}$ & $361.06 \mathrm{a}$ & 6.97 a & $21.10 \mathrm{a}$ & $0.30 \mathrm{a}$ & $2.64 \mathrm{a}$ & $0.053 \mathrm{a}$ & $29.00 \mathrm{a}$ \\
\hline & $\mathrm{S}$ & $10.80 \mathrm{~b}$ & 367.81 a & $8.40 \mathrm{~b}$ & $13.25 \mathrm{~b}$ & $0.28 \mathbf{a}$ & $3.04 \mathrm{a}$ & $0.070 \mathrm{~b}$ & $33.00 \mathrm{a}$ \\
\hline & $\Delta$ & 3.64 & 6.75 & 1.43 & 7.85 & 0.02 & 0.40 & 0.017 & 4.00 \\
\hline
\end{tabular}

Significant differences between means $(p<0.05)$ were evaluated by ANOVA (all traits of $S$. nitida and A. sempervirens; seed traits of all species) and ANCOVA using

biomass as covariate (leaf, whole plant, and clonal traits of $L$. corniculatus and $T$. longicaulis). Significant differences are indicated by different lower case letters in bold.

Identical lower case letters indicate homogeneous groups, i.e. no significant difference 
Table 5 Intraspecific trait-environment relationships of the study species within habitats (i.e. N: northfacing slope, S: south-facing slope)

\begin{tabular}{|c|c|c|c|c|c|c|c|c|}
\hline \multirow[b]{2}{*}{ Habitat } & \multicolumn{2}{|c|}{ Lotus comiculatus } & \multicolumn{2}{|c|}{ Astragalus sempervirens } & \multicolumn{2}{|c|}{ Thymus longicaulis } & \multicolumn{2}{|c|}{ Sesleria nitida } \\
\hline & $\mathbf{s}$ & $\mathrm{N}$ & $\mathbf{s}$ & $\mathrm{N}$ & $\mathbf{s}$ & $\mathrm{N}$ & $\mathbf{s}$ & $\mathrm{N}$ \\
\hline SLA & n.s. & n.s. & $\mathrm{NO} 3(+)^{*}$ & n.s. & n.s. & n.s. & n.s. & n.s. \\
\hline LDMC & n.s. & n.s. & n.s. & n.s. & n.s. & $\begin{array}{c}\mathrm{K}(-)^{*} \\
\mathrm{Mg}(+)^{*}\end{array}$ & n.s. & n.s. \\
\hline Height & $\begin{array}{l}\text { light(+)** } \\
\text { temp }(-)^{*} \\
\mathrm{CN}(+)^{*}\end{array}$ & temp $(-)^{* *}$ & $\operatorname{temp}(-)^{* *}$ & n.s. & n.s. & n.s. & n.s. & n.s. \\
\hline $\begin{array}{l}\text { Horizontal } \\
\text { stem lenght }\end{array}$ & n.s. & n.s. & no data & no data & n.s. & $\mathrm{NH} 4(-)^{*}$ & n.s. & $\begin{array}{c}\mathrm{Mg}(+)^{* *} \\
\mathrm{~K}(-)^{*} \\
\mathrm{P}(-)^{*} \\
\text { cond }(-)^{*}\end{array}$ \\
\hline $\begin{array}{c}\mathrm{N} \text {. of } \\
\text { bifurcations } \\
\text { I nodes per } \\
\mathrm{cm}\end{array}$ & n.s. & n.s. & non clonal & non clonal & n.s. & $\begin{array}{c}\text { light }(+)^{*} \\
\mathrm{NOB}^{*}(-)^{*} \\
\text { moist(-) } \\
\mathrm{K}(-)^{*}\end{array}$ & n.s. & n.s. \\
\hline $\begin{array}{c}\text { Distance } \\
\text { between } \\
\text { bifurcations } \\
\text { I nodes }\end{array}$ & $\begin{array}{c}\mathrm{pH}(-)^{* *} \\
\text { temp }(+)^{*}\end{array}$ & n.s. & non clonal & non clonal & n.s. & $\begin{array}{c}\mathrm{K}(+)^{*} \\
\mathrm{Mg}(+)^{*} \\
\mathrm{P}(+)^{*}\end{array}$ & n.s. & n.s. \\
\hline
\end{tabular}


(a)

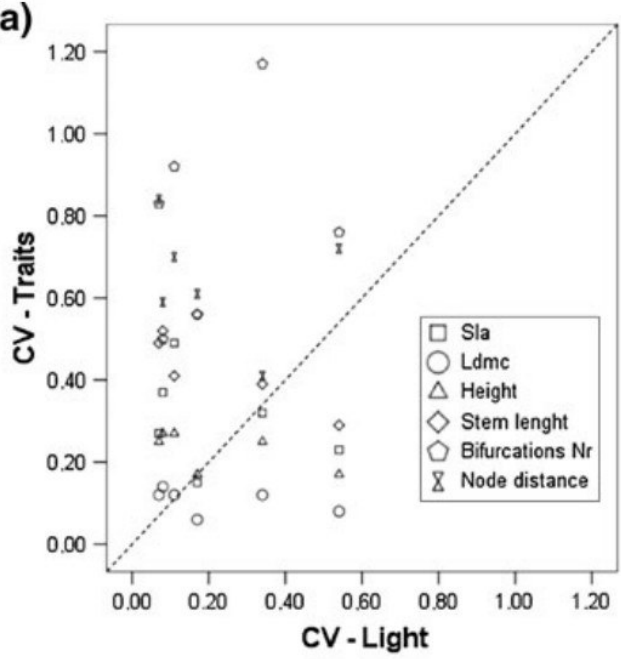

722

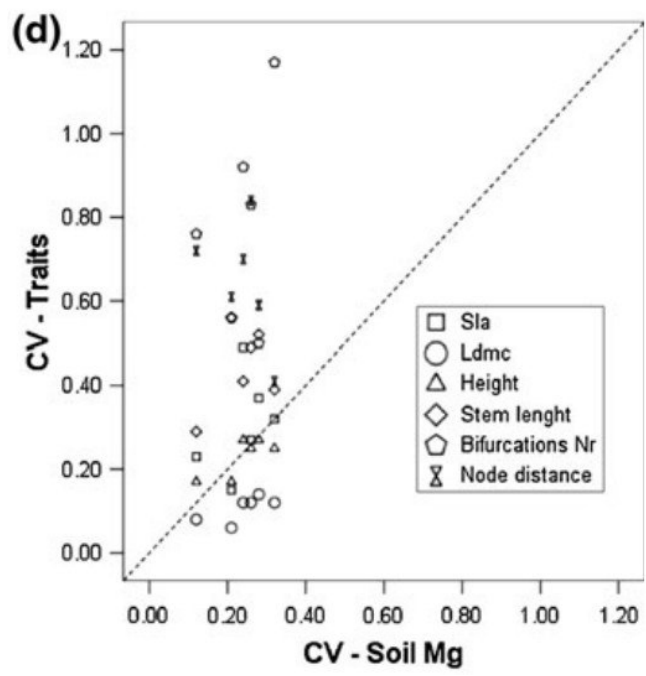

(b)

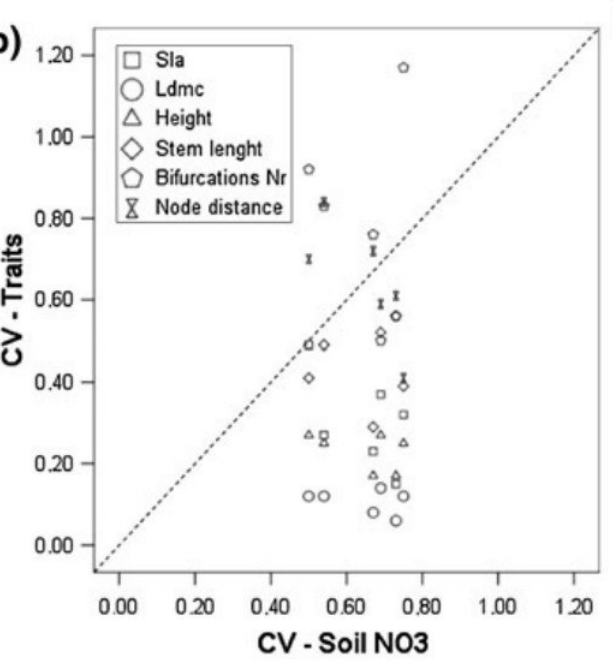

(e)

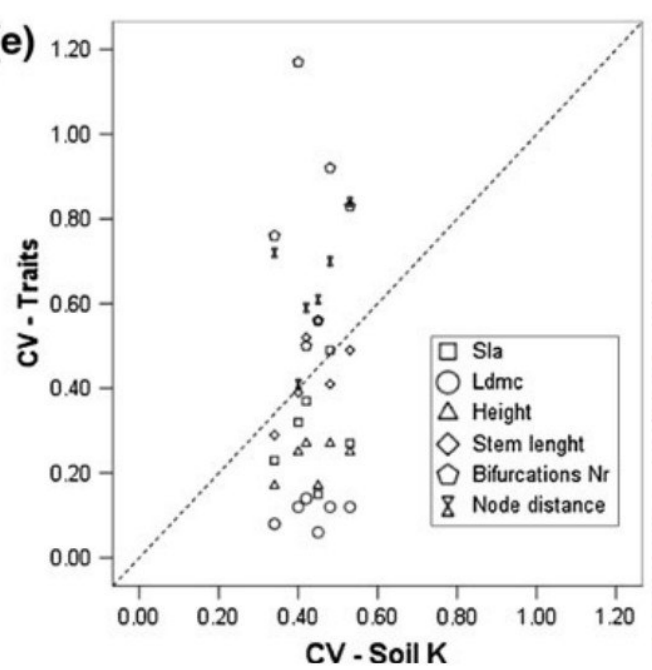

(c)

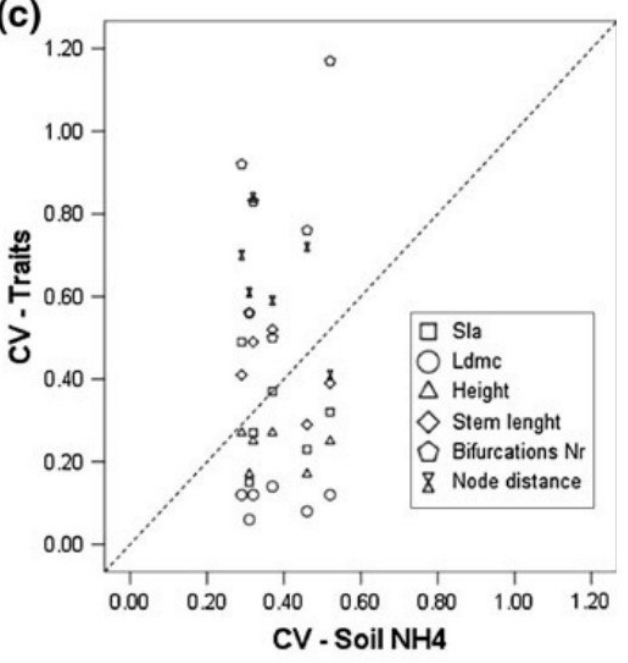

Fig. 1 Relationships between the intraspecific variation of plant traits (CV-traits) and the variability of environmental parameters [CV-environmental parameter, i.e. availability of light (a), nitrate (b), ammonium (c), magnesium (d) and potassium (e)] within habitats measured as the CV. The reference line indic ates if the magnitude of variation of plant traits corresponds to the magnitude of variation of the respective environmental parameter. Each point represents the CV of a trait of a particular species within one habitat (i.e. north or south slope). As no meaningful differences emerged between the north and the south slope in terms of CV-trait to $\mathrm{CV}$-environment relation they were not differentiated in the legend. All data on CVualues are prowided in the online resource ESM 2 
